\title{
Strategies in Teaching Speaking used by Teachers of Young, Junior High School, Senior High School, and University Students
}

\author{
Heidy Wulandari
}

\author{
STKIP SOE, SOE-TTS \\ heidywulandari0@gmail.com
}

Article History: Submitted November 12 $2^{\text {th }}, 2020$; Accepted December 28 ${ }^{\text {th }}, 2020$; Published December $30^{\text {th }}$, 2020

\begin{abstract}
This study aims at describing strategies in teaching speaking adopted by teachers of different student levels. The method used was descriptive qualitative method with 32 participants. The instrument was interview in the form of focused group discussion. The data were analyzed using open coding and categorization. The result shows that teachers of all levels tend to consider students' needs, the components of teaching speaking, and the media. For young learners, the teachers use discussion, story-telling, speech, guessing game, problem solving, and simulation. Games, modeling, electronic media, and instruction are suggested by the teachers as additional strategies. Meanwhile the strategies used for teaching speaking to junior high school students are discussion, story-telling, guessing game, and role play. Direct speaking is suggested as additional strategy. Moreover for teaching speaking to senior high school students, the teachers choose strategies such as discussion, story-telling, speech, guessing game, role play, problem solving, simulation, information gap, and jigsaw. Additional strategies suggested by the teachers are building sentences from root, talking stick, team game tournament, think pair and share, snowball throwing game, think, discuss and share, talking English directly, give and take model, time token model, repeat pronouncing words, and media and teacher as model. Then for teaching speaking to university students, the strategies chosen are role play, discussion, story-telling, problem solving, speech and simulation, guessing game, and information gaps. The additional strategies suggested by the teachers are hot seat and presentation. Finally, it is recommended that the further research will take time limitation, and the strategies strengths and weaknesses into account.
\end{abstract}

Keywords: speaking, strategies, teaching

Abstrak. Penelitian ini bertujuan untuk mendeskripsikan tentang strategi mengajar berbicara bahasa Inggris yang dipakai guru dalam mengajar siswa dengan level berbeda. Metode yang digunakan adalah metode kualitatif deskriptif dengan 32 partisipan. Instrumen yang digunakan adalah wawancara dalam bentuk fokus grup diskusi. Analisis data dilakukan dengan koding dan kategorisasi. Hasil analisa menunjukkan bahwa guru cenderung mempertimbangkan kebutuhan siswa, komponen dalam mengajar speaking, dan media. Untuk mengajar anak-anak guru menggunakan strategi diskusi, bercerita, berpidato, tebak-tebakan, penyelesaian masalah, dan simulasi. Permainan, model, media elektronik dan instruksi disarankan oleh para guru sebagai strategi tambahan. Sementara itu untuk mengajar berbicara bahasa Inggris pada siswa SMP, strategi yang digunakan adalah diskusi, bercerita, tebak-tebakan, dan bermain peran. Berbicara langsung disarankan sebagai strategi tambahan. Selain itu, untuk mengajar berbicara bahasa Inggris pada siswa SMA, guru memilih strategi seperti diskusi, bercerita, pidato, tebak-tebakan, bermain peran, penyelesaian masalah, simulasi, gap informasi, dan jigsaw. Strategi tambahan yang disarankan oleh para guru adalah membuat kalimat dari akar kata, tongkat berbicara, turnamen tim, berpikir, berpasangan, dan berbagi, lempar bola salju, berpikir, berdiskusi, dan berbagi, berbicara langsung bahasa Inggris, memberi dan menerima, model token 
waktu, dan mengucapkan kata berulang. Kemudian untuk mengajar mahasiswa, strategi yang dipilih adalah bermain peran, diskusi, bercerita, penyelesaian masalah, berpidato dan simulasi, tebak-tebakan, dan gap informasi. Strategi tambahan yang disarankan oleh para guru adalah kursi panas dan presentasi. Penelitian ini tidak mempertimbangkan kekurangan dan kelebihan dari setiap strategi. Oleh karena itu aspek kekurangan dan kelebihan dari strategi mengajar speaking di level berbeda sangat direkomendasikan bagi penelitian selanjutnya.

Kata kunci: berbicara bahasa Inggris, mengajar, strategi

\section{INTRODUCTION}

English as lingua franca is now realized by everyone. People make effort to master English. Parents start to send their children to bilingual schools or even full English schools. Other people try to attend many private English courses. The rest even choose to have long distance learning. Related to all efforts done by people to develop their ability of using English as a lingua franca, one of the four skills in English teaching and learning which gets most attention is speaking. Since speaking is the main focus in the use of English as a lingua franca, people do many efforts to be able to speak English.

As the demands of becoming fluent in English increases, English teachers are supposed to provide effective strategies in teaching speaking so the students' goal of becoming fluent in speaking English can be achieved. Moreover, in this digital era, teachers are demanded of being able to be very innovative and creative so they may be able to use internet to help them manage their classes. Motteram (2013) states that the existence of technology helps teachers to realize what they are doing. Have they met the students' needs in teaching and learning? Have their strategies stimulated the students to participate a lot in the classroom?

Answering the questions, Anjaniputra (2013) mentions that teachers who use cooperative activities, role play, creative tasks, and drilling in teaching their secondary level students succeed to help students improving their speaking ability. Moreover Rianingsih (2015) raises proof of intensive program teacher's creativity in solving students' speaking difficulties. In the study it is found that lecturing, reviewing, sharing, discussion and telling story do not help students to improve their speaking skill. Meanwhile debate, role play, prepared talks, interview, games, and brainstorming are effective in improving the students' speaking ability. Moreover, Kuning (2019) proposes types of technologies that can be used by teachers in teaching speaking consisting of Communication lab, Video conferencing, video library, CALL (Computer Assisted Language Learning), TELL (Technology Enhanced Language Learning) Podcasting, Quick Link Pen, Quicktionary, Programs through educational satellites, Speech Recognition Software, Internet, and Blogging.

Considering the previous studies which investigate strategies in teaching speaking in certain level of students, this research aims at describing strategies adopted by Indonesian teachers of different levels of students in teaching speaking. In this case, the current study will present the different strategies applied by teachers of different level of students. Compared to the previous studies which only focus on one level of students, this study will provide how strategies are implemented differently to teach speaking to young learners, junior high school students, senior high school students, and university students. Hence 
the research question is, "What strategies in teaching speaking do teachers adopt on different student levels?”

Seeing the status of English as a language and a lingua franca which is mostly used as a media for presenting ideas orally, speaking becomes very important. According to Murphy in Widyaningsih (2016), a significant goal for ESL students is becoming able to speak coherently and intelligibly on a focused topic.

Even though speaking is a significant goal for ESL students, it does not mean that only students take the responsibility to improve their ability in speaking English. Both, teacher and students play important role in improving speaking ability.

As presented in curriculum 2013 document, teacher is the main educational power who improves idea and plan to teaching and learning process. Taking that role, teacher has to provide learning process which support students' needs of being fluent in speaking English. Canado (2010, p. 105) suggests that teacher needs to leave traditional roles in teaching English as director, instructor, and source of information but transforms into modern teacher who acts as motivator, modifier, stimulator, creator of a positive classroom atmosphere, counselor, tutor, adviser, guide, helper, facilitator, resources, observer, participant, planner, supervisor, and investigator.

Seeing teachers' roles suggested by Canado, it can be stated that in English language teaching, teacher is not the center in the classroom. In this case, in relation to teaching speaking, teacher needs to provide creative strategies to help students to be fluent in speaking English without trying to become the director, instructor or source of information.

Porter (2012) defines strategy as unique approach of an organization in achieving its goals and how to deliver its value. Moreover according to Nickols (2016, p.7) strategy is "perspective, position, plan, and pattern." He adds that the formulation of a strategy relies on the goal to be achieved. Therefore, the strategies in teaching speaking must be matched to the objectives of speaking teaching and learning.

In order to choose the best strategy to teach speaking, teacher needs to consider time allocation for teaching speaking. Nation $(2007$, p. 3) proposes balance opportunities in teaching English through four strands which consist of meaning focused input, meaning focused output, language focused learning, and fluency development. Nation states that speaking and writing are parts of meaning-focused output which have to be taught in balance opportunity with other strands. Thus, by offering $25 \%$ of the course time for each strands, Nation provides $25 \%$ course time for meaning focused output. In this case, teaching speaking only gets approximately $12.5 \%$ of the course time to be held.

Seeing this, teacher has to choose strategies which can be used effectively for improving students' speaking ability without wasting too much time. Responding to this, Maulidar, Gani, and Samad (2019) suggested strategies of teaching speaking with time consideration which consists of role play, drilling, games, describing pictures, and group discussion. Rahayu (2015) states that role play is an appropriate strategy to help students express themselves through speaking. Meanwhile drilling according to Permana, Hidayatullah, and Hafizah (2018) is effective for improving students' speaking skill. Moreover games are considered helpful and encouraging for students with speaking difficulties (Dewi, Kultsum, and Armadi, 2017). Next Karsono (2014) mentions describing pictures as a working strategy in improving students' speaking fluency, content, pronunciation, and grammar. 
Finally, group discussion is considered effective in teaching speaking by Bohari (2019) who conducted experimental study on group discussion in teaching speaking.

Besides, since speaking is included into meaning focused output (Nation 2007), the strategies chosen by the teachers have to stimulate the students to produce their oral skills. Hence students' roles as autonomous, independent, active, participative, and creative learners who are involved in the decision-making process must be taken into consideration in formulating the strategies (Canado 2010, p. 106).

In addition, the components of speaking skill such as pronunciation, grammar, vocabulary, fluency, and comprehension are crucial in choosing strategies to teach speaking (Harris in Meilyaningsih, 2015). Nation (2009, p. 75) states that pronunciation is the reason why teachers and learners consider speaking English difficult. Therefore, in order to solve this problem, teachers have to have effective strategy in teaching pronunciation. Meanwhile Debata (2013) relates grammar and speech as two inseparable components of language in which "knowing a language means using its grammatical patterns as well as proper usage". Besides, Alqahtani (2015) points out that vocabulary knowledge is the core of communicative competence and second/foreign language acquisition. Khan, Radzuan, Shahbaz, Ibrahim, and Mustafa (2018) insist that the inability of speaking is caused by the lack of vocabulary. Moreover Shahini and Shahamirian (2017) say that fluency means delivering intention using speech quickly and confidently. In this case fluency cannot be separated from speaking. Last but not least, comprehension is the key of communication in English (Howlader in Marza, 2014). Thus in teaching speaking, teachers are demanded to choose appropriate strategies which can improve students' ability in comprehending English speech.

\section{METHOD}

This research was conducted using descriptive qualitative method. The instrument used in this research was interview in form of Focused Group Discussion. There were 32 Indonesian EFL (English as a foreign language) teachers who teach young leaners, junior high school, senior high school, and university students involved in Focused Group Discussion for the data collection. In the discussion, the researcher started with mentioning a list of strategies of teaching speaking to be discussed. The discussion involve whether the teachers use the strategies or not, how the strategies are implemented and the strengths and weaknesses of the strategies. Moreover, the teachers added other strategies that are not mentioned by the researcher in the discussion. The discussion was recorded and the data were transcribed. The analysis was done using open coding and categorization. Lin and Bates (2014, p. 32) define open coding as the process of developing categories of concepts and themes emerging from data. Teachers' answers in the focus group discussion which has been transcribed were coded. From the coding process, there appeared specific codes which then were categorized into strategies in teaching speaking to elementary students, junior high school students, senior high school students, and university students.

\section{RESULTS AND DISCUSSION}

In this part, the result of the study will be presented and the discussion of the results will be elaborated. The result will be the answer of the research question, "What strategies in teaching speaking do teachers adopt on different student levels?" Meanwhile the 
discussion will be the detail explanation of the results by considering the teachers' experience in using strategies to teach speaking to students with different levels.

\section{Results}

Answering the research question, the strategies that are used by the teachers are categorized based on the the categories found from the data analysis. The strategies consist of strategies in teaching speaking to young learners, junior high school students, senior high school students, and university students. The strategies are chosen by the teachers after considering the needs analysis and the focus of teaching speaking. Besides, the teachers also add more strategies for each level in additional strategies and media. The following table shows the categories of the strategies.

Table 1 Strategies to Teach Speaking to Different Levels of Students

\begin{tabular}{|c|c|c|c|c|}
\hline Level & $\begin{array}{c}\text { Ways to } \\
\text { Consider } \\
\text { Students' Needs }\end{array}$ & $\begin{array}{l}\text { Components of } \\
\text { Speaking }\end{array}$ & $\begin{array}{c}\text { Strategies to } \\
\text { Teach Speaking }\end{array}$ & $\begin{array}{c}\text { Additional } \\
\text { Strategies and } \\
\text { Media } \\
\end{array}$ \\
\hline $\begin{array}{l}\text { Young } \\
\text { Learners }\end{array}$ & $\begin{array}{l}\text { pretest } \\
\text { observation } \\
\text { senior teachers } \\
\text { consultation } \\
\text { parents interview }\end{array}$ & $\begin{array}{l}\text { pronunciation } \\
\text { intonation } \\
\text { fluency } \\
\text { vocabulary }\end{array}$ & $\begin{array}{l}\text { discussion } \\
\text { storytelling } \\
\text { speech } \\
\text { guessing games } \\
\text { problem-solving } \\
\text { simulation }\end{array}$ & $\begin{array}{l}\text { games } \\
\text { modeling } \\
\text { electronic media } \\
\text { (movie) } \\
\text { instruction. }\end{array}$ \\
\hline $\begin{array}{l}\text { Junior High } \\
\text { School } \\
\text { Students }\end{array}$ & $\begin{array}{l}\text { students' skills } \\
\text { students' needs } \\
\text { assessment. }\end{array}$ & $\begin{array}{l}\text { pronunciation } \\
\text { intonation } \\
\text { fluency } \\
\text { grammatical } \\
\text { accuracy }\end{array}$ & $\begin{array}{l}\text { discussion } \\
\text { story-telling } \\
\text { guessing game } \\
\text { role play }\end{array}$ & $\begin{array}{l}\text { direct speaking } \\
\text { movie } \\
\text { pictures } \\
\text { cards } \\
\text { living object }\end{array}$ \\
\hline $\begin{array}{l}\text { Senior } \\
\text { High } \\
\text { School } \\
\text { Students }\end{array}$ & $\begin{array}{l}\text { feedback } \\
\text { asking questions } \\
\text { pretest } \\
\text { students' natural } \\
\text { performance } \\
\text { analysis } \\
\text { needs assessment } \\
\text { dialogues } \\
\text { text }\end{array}$ & $\begin{array}{l}\text { pronunciation } \\
\text { grammatical } \\
\text { accuracy } \\
\text { intonation } \\
\text { fluency }\end{array}$ & $\begin{array}{l}\text { discussion } \\
\text { story-telling } \\
\text { speech } \\
\text { guessing game } \\
\text { role play } \\
\text { dialogue } \\
\text { problem solving } \\
\text { simulation } \\
\text { information gap } \\
\text { jigsaw }\end{array}$ & $\begin{array}{l}\text { sentences from root } \\
\text { talking stick } \\
\text { teams games } \\
\text { tournament } \\
\text { think pair and share } \\
\text { snowball throwing } \\
\text { game } \\
\text { think, discuss and } \\
\text { share, } \\
\text { talking English } \\
\text { directly } \\
\text { give and take model } \\
\text { time token model } \\
\text { repeat pronouncing } \\
\text { words } \\
\text { media and teacher as } \\
\text { model } \\
\text { movie } \\
\text { card } \\
\text { poster } \\
\text { song }\end{array}$ \\
\hline $\begin{array}{l}\text { University } \\
\text { Students }\end{array}$ & $\begin{array}{l}\text { asking students' } \\
\text { feelings }\end{array}$ & $\begin{array}{l}\text { pronunciation } \\
\text { grammatical }\end{array}$ & $\begin{array}{l}\text { role play } \\
\text { discussion }\end{array}$ & $\begin{array}{l}\text { hot seat } \\
\text { presentation }\end{array}$ \\
\hline
\end{tabular}




need analysis
before
developing
materials
needs analysis in
the beginning of
the meetings

accuracy

intonation

fluency

developing

needs analysis in

the meetings
story-telling
problem solving
speech
simulation
guessing game
information gaps.
movie
pictures
cards
living objects

It can be seen from the table above that the strategies chosen by the teachers are similar among the levels. It means that discussion, role play, storytelling, problem solving, speech, simulation, guessing game, and information gaps are used by teachers in teaching speaking to any level of students. The focus of teaching speaking also covers pronunciation, grammatical accuracy, intonation, fluency, and vocabulary. However it can be seen in the table that teachers also do needs analysis with various ways which then determine how the strategies will be applied according to the students' level. The additional strategies and media that are suggested by teachers also show how rich the teachers are in facilitating their classes for the students' speaking skill improvement.

\section{Discussion}

As mentioned in the result, the strategies to teach speaking are categorized into the strategies to teach speaking to young learners, junior high school students, senior high school students, and university students. Each category will be elaborated in this section by considering the way the teachers analyze the students' needs, the focus in teaching speaking, the strategies the teachers choose to teach speaking and how they implement them, additional strategies and media that the teachers use to teach speaking and the reason why they choose those strategies.

\section{Strategies in Teaching Speaking to Young Learners}

In this study, young learners are those who study in kindergarten and elementary schools. Since considering students' needs is important in choosing appropriate strategy for teaching speaking, from six teachers who teach speaking in elementary schools only one teacher does not consider students' needs. The rest considers students' needs by doing pretest through questions and reading test, observing the students' interests and daily activities, consulting with senior teachers, and interviewing the parents related to the students' characteristics and what they want for the children.

These young-learners teachers also have the same focus in teaching pronunciation as the most important aspect for teaching speaking to young learners. Their reason is because young learners just need to know how to pronounce words. To them, grammar is still difficult for young learners. It can be seen from the result that beside pronunciation, only two teachers consider grammar to be focused on. In addition intonation and fluency are only given attention by one teacher for each. Besides pronunciation, intonation, fluency, and grammatical accuracy, a teacher suggests vocabulary as the main focus in teaching speaking.

For the strategies of teaching speaking to young learners, two teachers choose discussion in order to encourage the students to speak among friends and to create two-ways 
communication. One of the teacher do this by giving questions to be discussed while the other gives a topic to be discussed by the students in groups.

Story-telling is chosen by three teachers with purpose to enrich students' vocabulary. In general these teachers do the strategy by telling a story. They use pictures while telling the story to help the students acquire the vocabulary naturally. After that, they mention the new vocabulary related to the pictures and followed by the students. Then the students are given chances to retell the story or tell other story according to the given topic.

The next activity, speech, is used by one of the teachers to teach speaking to grade five of elementary students. She chose this activity to encourage the students to read some material and write for the speech and speak individually. She does this by giving several topics to the students. The students can choose one topic and prepare a speech.

Then three teachers chose guessing games as the strategy for teaching speaking to attract students' involvement in speaking activity, to enrich vocabulary, and to review material. They do this by using cards and pictures. The game can be done by guessing the name of animals described by the teachers based on the picture on hidden card. The student who can guess it may take the role for describing the picture on other hidden card. On the other way, the teacher provides many pictures and students mention the name, or students take the correct picture based on teacher's instruction.

Problem-solving strategy is chosen by two teachers to encourage students to actively speak and increase the number of their vocabulary. These teachers asked questions on a certain problem, and then the class discusses to find the solution.

One of the young-learners teachers chooses simulation as a strategy for teaching speaking to improve the students' pronunciation. This teacher uses picture and video as the model and let the students imitate the pronunciation.

Besides the researcher's strategies, these teachers add strategies to teach speaking consisting of games, modeling, electronic media, and even instruction. Games are often used as the main activity and sometimes to review the material. In modeling, students are usually become model for their friends by following the turn list for being a leader in class made by the teacher. Electronic media such as movie, song or material from internet is also used as strategy to teach speaking depending on the material that the teacher needs to teach. Since one of the teacher consider using English as a medium of instruction as the basic thing to make students be familiar and fluent in speaking English, she usually speaks English while teaching and rarely speaks Indonesian. She also motivates her students to speak English in the process of teaching learning process.

In order to support the strategies, these teachers use certain media. Four teachers choose movie as the media for teaching speaking. They have similar reasons that beside attracting the students' attention, movie can help students to understand contextually while learning to pronounce. Besides that, by using movie, one of the teachers relates the students' interest of moving objects and pictures or animation to easy learning.

\section{Strategies in Teaching Speaking to Junior High School Students}

In teaching speaking to Junior High School Students, it is also important to consider students' needs. Therefore, from three teachers, two of them consider students' needs 
before teaching speaking to their students. The first of these two teachers pay attention on the students' skills. Therefore he focuses on which skill is needed to be improved. The other one gives sentence, then she asks them to read it one by one to check how they pronounce the words in the text. After that, she makes students' needs assessment. The only one who does not consider his students' needs just teach based on the curriculum.

Similar to the teachers of young learners, teachers of Junior High School students also focus most on pronunciation while teaching speaking. It can be seen from the data that these three teachers choose pronunciation as their focus when teaching speaking while the other aspects such as intonation, fluency and grammatical accuracy are only chosen by one teacher for each. They choose pronunciation because in general they think that students can communicate well if they have good pronunciation. The one who chooses grammatical accuracy as the focus in teaching speaking wants the students to speak based on grammatical rule. The rest who chose fluency and intonation consider these two aspects as important aspect in speaking.

For the activities, only one teacher chooses discussion as one of his strategies in teaching speaking to make the students participate actively. He divides the students into some groups or pairs and gives them a familiar topic to discuss in a few minutes. After that the students present their result of discussion.

Story-telling is also chosen by one teacher to stimulate the students to produce words. This teacher tells the students a story. After that he asks them to retell the story by their own ways.

Guessing game is chosen by two teachers to enrich the students' vocabulary, to improve their ability in describing things, and to develop their speaking skill. One of these two teachers does this by asking students to match some pictures and also make sentences based on the pictures. The other teacher gives a word to a student. Then the student provides three clues and the other students guess the word. The student who can guess the word, take turn to describe another word given by the teacher.

Then role play is chosen by one teacher to improve pronunciation and confidence in speaking English. This teacher does this in groups. Unfortunately, he does not give more explanation about how to do conduct this activity.

One of these three teachers also suggests a strategy in teaching speaking that is Direct Speaking. Direct speaking is actually using English as medium of instruction to make the students accustomed to speak English. So this teacher teaches and asks the students in English and the students must respond in English.

To support their strategies in teaching speaking, two teachers choose movie as the media because students love watching movie and are more interested in retelling about something that they see from the movie than to retell a passage in the textbook. Besides that, movie can also improve students' critical thinking because after watching the movie, the students are asked to tell their perspectives about the movie.

Pictures and cards are also chosen by two teachers as media in teaching speaking because they think that pictures and cards will stimulate the students to express their idea or opinion and therefore can encourage them to speak. One teacher chooses living objects with the same reason as pictures and cards. 


\section{Strategies in Teaching Speaking to Senior High School Students}

Students' need is not only important in teaching young learners and Junior High School students but also Senior High School students. It can be seen from the data analysis that seventeen from eighteen teachers analyze their students' needs before they teach speaking.

One of the teacher analyses the students' needs by paying attention on the result of their work in the previous meeting. From the result of that analysis, this teacher finds their weaknesses and their strength. Then, he considers their weaknesses as their needs. After that, he determines what kind of teaching method of speaking which can be applied to help the students to fulfill their needs. Other seven teachers do needs analysis by asking questions. The questions are various consisting related material, students' interests, and even the students' difficulties in speaking. Some of these teachers use questions to stimulate students to speak so they can take notes on the students' weaknesses and strengths in speaking. One of the teachers uses pretest to analyze students' needs in learning speaking. Two other teachers do needs analysis during the process of teaching and learning when the students perform naturally. Two of these teachers make needs assessment but they do not explain in detail on how they conduct the assessment. Three of these teachers use dialogues, text or certain situation to stimulate the students to speak. When the students speak, they find which aspect is needed to be improved. The one who does not consider students' needs does not explain the reason.

For the aspects of speaking, sixteen teachers choose pronunciation as the focus for some reasons. First, good pronunciation can help communicators to understand each other so the communication can run well. Second, good pronunciation can help to increase students' confidence to speak English. Sometimes students' are ashamed to speak English because they have bad pronunciation. Third, English pronunciation is difficult so by having good pronunciation, English can become easy.

Other aspects are chosen together with pronunciation by eight teachers because they believe that all aspects are interrelated and cannot be separated in teaching speaking. Beside that those aspect take role in giving clearance of ideas and thoughts and to avoid misunderstanding.

In teaching speaking, twelve teachers choose discussion as the activity with generally similar purposes. The purposes are to help students to be cooperative, active, and be confident to deliver their ideas. Besides that, discussion is also used to help teacher check students' ability to speak. These teachers do discussion in similar way by dividing the students into groups, discuss, present the result of discussion, and other groups give response to the presentation. However they have various material to be discussed consisting worksheet, questions, certain topic, case, text, dialogue, ideas, and issues.

Seven teachers choose story-telling to build up students' confidence when speaking in front of many people, to enrich their vocabulary, to enhance their speaking ability, to enable them to produce words, to make them active and to develop their imaginative thinking. The ways these teachers implement story-telling are different. The first implementation is by giving a story text to the students and asking them to retell the story after reading for a few minutes. In this implementation, only one teacher asks students to write down clue words from the text so they can improve the story themselves. Second implementation is by dividing students into groups and giving the groups different stories. After that students are asked to make a summary of the story and finally they are asked to 
retell the summary in front of the class. The third implementation is by asking students to pick up stories from those provided by the teacher. Then the students are asked to read the stories with good pronunciation and intonation, memorizing it, and mimicry.

Speech is chosen by three teachers to increase students' speaking ability and enable them to deliver ideas. These teachers do this activity by giving themes or issues to the students or ask the students to choose a topic they are interested in. Then the students are asked to find more information related to the topic and write their speech with teacher's assistance. Finally, the students are asked to deliver their speech in front of the class.

Then four teachers choose guessing game to create a fun and interesting English class, to involve all students in speaking English, and to enrich students' vocabulary. This game is conducted by delivering some clues related to an object (people, animal, places, advertisements, etc.). Then let students guess the name of the object. Students who can guess correctly get the turn to give clues of another object. This game is also conducted by a teacher at the beginning of the class. Firstly, he divides students into two or four big groups. Then he asks one representative of each group to read the clue, then students in their group should guess the word or phrase. The word or phrase indicates the lesson topic they are going to learn. He gives them score for the right answers. He also gives them chance to grasp other group's turn if the group doesn't know the answer.

Nine teachers choose role play to improve students' pronunciation, to help students' to respect others while communicating, to create a contextual English learning, to develop students' creativity, and to develop students speaking fluency. Beside that role play is considered able to help students to interact with their partners and provides freedom to thee students to talk about everything they want to talk.

These teachers do the activity variously. The role play can be done in groups or pairs.

First way is by giving students dialogue. Then, asking the students to check the pronunciation of the words in the dialogue from dictionary. After that, asking the students to pronounce every word from the dialogue based on the pronunciation in the dictionary. When all are correct, they students perform the dialogue in front of the class.

Second way is done by giving chance to students to practice and act a conversation with their own expression, gesture, and mimic to show the characters in the conversation.

Third way is done by giving the students scenario, and then asking them to create their own dialogue script based on the role they want to play. The teacher guides the students to create their own dialogue script and practice with them first. Students can ask the pronunciation of words which they don't know. Then the teacher prepares role play cards for students to help them managing their role in conversation. The scenario needs two or more than two students to play so that they will not feel shy to play in front of the class.

The fourth way is done by dividing students into groups, asking them to choose role they want to play, giving them scenario, guiding them to practice, giving them chance to play in front of the class, and evaluating their role play.

Fifth way is done by providing a situation or topic, asking the students to make a dialogue based on the situation or topic given, and then then practice the dialogue in front of class. 
Problem solving, simulation, and information gap are only chosen by one teacher for each. Problem solving is chosen to enable students to find or create solution or way out of a certain problem or case. This activity is done by giving a case, guidelines, let the students find out the way out of the case, and present the result. Simulation is chosen to stimulate the students to speak based on the situations they see. This activity is done by doing a simulation of a certain phenomenon. Then the students are asked to express what they feel related to the simulation. Information gap is chosen to improve students' pronunciation and enable them to find information. This activity is done by divide the class into several groups and giving each group same incomplete text with different missing parts. All the students have to do is discuss with other groups to find the information in order to fill the missing part of their own text.

Then jigsaw is chosen by three teachers to increase students cooperation. This activity is done by two different ways. First way, cut out a paragraph into sentences and give one each to a student and they have to reconstruct the paragraph by communicating with one another (same as in formation gaps). Second way, divide the students into groups. Then give different topic to each group to be discussed. Then the result of discussion has to be shared to other groups.

Beside the strategies above, the teachers suggested other strategies as build sentences from the root of word, talking stick, teams games tournament, think pair and share, snowball throwing game, think, discuss and share, talking English directly, give and take model, time token model, repeatedly pronouncing words, media, and teacher as model.

For the strategy build sentences from the root of word, the students are asked to memorize the vocabulary then search the words related to the word for example: train-trainingconstrain-detrain etc. Then the teacher asks them to classify the words' part of speech. After that the students are divided into groups to make sentences or a short conversation using the words they find.

Talking stick is used by a teacher to teach expression. This teacher provides a situation and while giving a stick to a student. Then, the student must respond by saying an appropriate expression. The activity is done in turn until all students in the classroom get chance to use expression. This strategy is also used by another teacher to review material. This teacher asks the students to sing a song while distributing a stick. The student, who holds the pen at the end of the song, must pronounce some words prepared by teacher. Other teacher gives material to students to be read and learnt. Then a stick will be given to student randomly. The student who gets the stick must answer a question given by the teacher.

Teams-games-tournament is done by dividing the students into some groups. Each group consists of students with high, average and low English proficiency. They study certain material in their group. Then, students who have high ability can help another who has low ability. After that, students in the same level from all groups will to answer questions given by teacher.

Think pair and share is done by dividing students into pairs, giving them a problem to be solved. After that the students must share the result of their discussions with other pairs. This strategy can be used in groups named 'think, discuss and share' with same way. 
Snow ball throwing games is done by asking students to prepare expression and its response. Then a student throws a rolled paper as snow ball while saying an expression or situation to another student who has to respond to the expression or situation.

Talking English Directly is done by using English as media of instruction. The teacher starts the class by talking English to students or telling them a story, asking their opinions and asking them to respond in English.

Give and Take Model is done by preparing a few cards with different sub topics. Each student will get one card. They must talk about the sub topics and share it to others students.

Time Token Model can be used for teaching descriptive text. The teacher asks students to describe about Agnes Mo. Each student gets 2 coupons. It means that each student has 2 chances to talk in 5 second. Before they talk they must submit the coupons to teacher.

Repeatedly pronouncing words is done by asking the students to perform dialogues. Then the students list difficult words from the dialogue. Then the teacher pronounces the words and repeated by the students.

Media for instance is done by showing the students a movie or anything that they are interested in. Then the teacher asks for their opinion.

Teacher as model is done by speaking English first and then followed by the students.

For supporting the activity, eleven teachers use movie for some reasons. First, because movie is attractive, can help students to learn contextually, to know how expressions are used, and to directly learn pronunciation. Thirteen teachers use picture because it is easy, fun, and interesting. It can stimulate students to build up their own dialogue or text and improve their critical thinking through contextual learning. Two teachers choose living object (native speaker) to help the students to hear directly how a word is produced. Card is chosen by two teachers because students are helped to think about what they need to speak, enrich their vocabulary, interact with real object, and interesting.

These teachers suggest other media consisting poster and song. Poster is helpful to elicit the students' background knowledge and vocabulary while song can help students to know word meaning without any burden.

\section{Strategies in Teaching Speaking to University Students}

It cannot be denied that students' needs are very important in teaching speaking. Beside young-learners teachers, junior high school teachers and senior high school teachers, university teachers also consider students' needs. It can be seen from data analysis that all three teachers in this research consider their students' needs before teaching speaking. One teacher asks the students to express what they feel to measure their speaking ability. The other conducts need analysis before developing materials for the class. Another one analyses the students' needs in their beginning of the meetings, usually in the first three meetings.

For the aspects of teaching, one teacher focuses on pronunciation and grammatical accuracy because she considers her students still need improvement in those two aspects. The second teacher focuses on grammatical accuracy because he considers grammatical 
accuracy as the base for the other aspects. To him, if the students are grammatically correct then it will increase it will increase the success in delivering the message of the speaker. The last teacher considers all aspects are important because to her those aspects are interrelated, cannot be separated from each other.

For activities in teaching speaking, these three teachers choose role play. One of the teacher gives guideline, explain, and ask the students to do and perform. Besides that, she also asks the students to make dialogue. The second teacher uses the role play in group to practice speaking. The third teacher uses role play to enhance help the students become communicative and able to respond in speaking activities. He asks the students to prepare a dialogue, practice it, and then perform it.

Then two of these three teachers choose discussion as one of the activities in teaching speaking. In order to practice speaking skills, the first teacher divides the students in groups and gives a certain topic to be discussed. The second teacher uses discussion to stimulate the elaboration of a topic. He finds a topic, gives questions, and asks for opinion.

Story-telling is also chosen by these two teachers. One of them asks students to retell a story from a text in group. The other teacher finds a topic, then brainstorms for stories. This teacher then asks a student tell the story, and the other students take turn to retell it after the student finishes. Finally, they discuss the story. The purpose is to share the experience of different students.

Beside story-telling and discussion, these two teachers also choose problem solving. One of them uses problem solving to practice speaking skill by letting the students discuss certain topics and propose the solution. The other teacher uses problem solving to make the students to think more critically by suggesting a problem, asking the students to brainstorm and discuss to find the solution and finally discussing the solution.

One teacher also chooses speech and simulation. He uses speech to nurture the ability to speak in front of public. He asks students to finds topic, brainstorm, write speech text, and perform. Simulation is used by this teacher to prepare the activities to achieve the highest mar. The steps he uses in simulation is preparing, then doing the simulation, and finally giving feedback.

The other teacher chooses guessing game and information gaps. Both activities are used for practicing speaking skill. This teacher conducts guessing game by using cards and other supported media while for information gaps, she does it in pairs. However she does not describe in detail how to conduct the activities.

Beside the activities mentioned above, there are hot seat and presentation suggested by the teachers. Every meeting, at the beginning of the class, one student sits on the hot seat and picks a topic to be shared with the whole class. At the end of the course, students are assigned to make a presentation with power point on certain topics. In the other way, presentation can be done by discussing specific topic and find possible aspect to present, then ask the students to present individually, or in group.

Besides doing the activities, these teachers also choose media to support them teaching speaking. One of the three teachers chooses movie, pictures, and living objects because these media are interesting. The other teacher also chooses pictures without giving reason why she chooses the media. The last teacher chooses movie because it is a good example 
to show the aspects of speaking activity, especially from natives. He also chooses pictures, living objects and cards to stimulate for topics.

\section{CONCLUSION}

The strategy of teaching speaking is various depending on the level of students. In this study, the level is categorized into young learners, junior high school students, senior high school students, and university students. On each level, teachers consider students' needs, the components of speaking such as pronunciation, grammar, vocabulary, and fluency. By considering those aspects, it is concluded that some strategies are applied in all levels but with different consideration and treatment. For young learners, the teachers use discussion, story-telling, speech, guessing game, problem solving, simulation, games, modeling, electronic media, and instruction. Meanwhile for teaching speaking to junior high school students, the strategies used are discussion, story-telling, guessing game, role play, and direct speaking. Moreover for teaching speaking to senior high school students, the teachers choose strategies such as discussion, story-telling, speech, guessing game, role play, problem solving, simulation, information gap, jigsaw, building sentences from the root of word, talking stick, team game tournament, think pair and share, snowball throwing game, think, discuss and share, talking English directly, give and take model, time token model, repeatedly pronouncing words, media, and teacher as model, talking stick, teams games tournament, think pair and share, snow ball throwing games, talking English directly, give and take model, time token model, and repeatedly pronouncing words. Then for teaching speaking to university students, the strategies chosen are role play, discussion, story-telling, problem solving, speech and simulation, guessing game, information gaps, hot seat and presentation. Even though there are a lot of strategies used by teachers in teaching speaking, none of them are chosen based on time consideration. Moreover, the current study does not consider the strengths and weaknesses of each strategy. Hence it is recommended that further research on similar issue may prioritize time limitation in choosing appropriate strategy to teach speaking and the strengths and weaknesses as well.

\section{REFERENCES}

Alqahtani, M. (2015). The importance of vocabulary in language learning and how to be taught. International Journal of Teaching and Education, 3 (3), 21-34 DOI: 10.20472/TE.2015.3.3.002.

Anjaniputra, A.G. (2013). Teacher's strategies in teaching speaking to students at secondary level. E-Journal on English Education, 1 (2), 1-8. Retrieved from http://ejournal.upi.edu /index.php/L-E/article/view/577/434.

Bohari, L. (2019). Improving speaking skills through small group discussion at eleventh grade students of SMA Plus Munirul Arifin NW Praya. Journal of Languages and Language Teaching, 7(1), 68-81. DOI: 10.33394/jolt.v7i1.1441

Cañado, M. L. P. (2010). The transformation of teacher and student roles in the European higher education area. Journal of Language Teaching and Research, 1 (2), 103 110. doi: 10.4304/j1tr.1.2.103-110. 
Debata, P. K. (2013). The importance of grammar in English language teaching: a reassessment. Language in India, 13 (5), 482-486. Retrieved from https://www.semanticscholar.org/paper/The-Importance-ofGrammar-in-EnglishLanguage-A-Debata/77f7b353709157dd061c6b2b67a4db284af53ff8.

Dewi, R.S., Kultsum, U., and Armadi, A. (2017). Using communicative gaes in improving students' speaking skills. English Language Teaching, 10(1), 63-71. DOI: 10.5539/elt.10n1p63.

Karsono, P. (2014). Using pictures in improving the speaking ability of the grade eight-A students of SMP Negeri 1 Anggana. Dinamika Ilmu, 14(2), 190-213. DOI: 10.21093/di.v14i2.3.

Khan, R.M.I., Radzuan, N.R.M., Shahbaz, M., Ibrahim, A.H., and Mustafa, G. (2018). The role of vocabulary knowledge in speaking development of Saudi EFL learners. Arab World English Journal (AWEJ) 9 (1), 406-418 https://doi.org/10.24093/awej/vol9no1.28.

Lin, M. and Bates, A. (2014). Who is in my classroom? teachers preparing to work with culturally diverse students. International Research in Early Childhood Education, $5(1), \quad 27-42$. Retrieved from https://bridges.monash.edu/articles/journal_ contribution/Who_is_in_my_classroom_teachers-preparing_to_work_with_ culturally_diverse_students/4141869.

Marza, N. E. (2014). Pronunciation and comprehension of oral English as a foreign language class: key aspects, students' perceptions and proposals. Journal of Language Teaching and Research 5, 2, 262-273 doi: 10.4304/jltr.5.2.262-273.

Maulidar, K., Gani, S. A., Samad, I. A. (2019). Teacher's strategies in teaching speaking for cadets. English Education Journal, 10 (1), 80-94. Retrieved from https://jurnal.unsyiah.ac.id/EEJ/article/view/13258.

Meilyaningsih, A. I. (2015). Improving the students' speaking ability through the use of role playing technique for grade viii students of SMPN1 Banguntapan in the academic year of 2013/2014 (Unpublished Master's Thesis). State University of Yogyakarta, Yogyakarta.

Motteram, G. (Ed). (2013). Innovations in Learning Technologies for English Language Teaching. United Kingdom: British Council.

Nation, P. (2007). The four strands. Innovation in language learning and teaching, 1 (1), 1 11 DOI: $10.2167 /$ illt039.0.

Nickols, F. (2016). Strategy: definition \& meanings. Retrieved from https://www. nickols.us/strategy_definitions.pdf\&ved=2ahUKEwiB2o3vxuztAhXTdCsKHZ3j DgAQFjACegQIBRAC\&usg=AOvVaw20FkrVHNkncqiAaBSlyUNO.

Permana D, Hidayatullah H, and Hafizah N. (2018). The effectiveness of chain drill technique in teaching speaking. Jurnal Kependidikan 17(2), 133-140. Retrieved from

https://www.researchgate.net/publication/336527079_The_Effectiveness_of_Chai n_Drill_Technique_in_Teaching_Speaking. 
Porter, M. E. (2012). What is strategy: issues for the World Bank. Washington: world bank strategy discussion. Retrieved from https://www.hbs.edu/faculty/Pages/item.aspx? num $=46827$.

Rahayu, P. (2015). Role play strategy in teaching speaking. Jurnal Ilmiah Edu Research, 4 (1), 61-70. Retrieved from https://www.e-journal.upp.ac.id

Rianingsih R. (2015). The teacher strategies in overcoming students' difficulties in speaking at english intensive program of MA An-nur Cirebon. (Unpublished Master's Thesis). IAIN Syekh Nurjati, Cirebon.

Shahini, G. and Shahamirian, F. (2017). Improving English speaking fluency: The role of six factors. Advances in Language and Literary Studies, 8(6), 100-104 DOI:10.7575/aiac.alls.v.8n.6p.100.

Widyaningsih, T.L. (2016). Enhancing students' speaking skill through debate technique. INSPIRASI (Jurnal Ilmu Sosial), 13 (2), 1-12. Retrieved from https://jurnal.stkippgritulungagung.ac.id/index.php/inspirasi/article/view/398/214. 